\begin{tabular}{|c|c|c|c|c|c|c|}
\hline \multirow{4}{*}{ Impact Factor: } & ISRA (India) & $=3.117$ & SIS (USA) & $=0.912$ & ICV (Poland) & $=6.630$ \\
\hline & ISI (Dubai, UAE & $=\mathbf{0 . 8 2 9}$ & РИНЦ (Russia & $=0.156$ & PIF (India) & $=1.940$ \\
\hline & GIF (Australia) & $=0.564$ & ESJI (KZ) & $=5.015$ & IBI (India) & $=4.260$ \\
\hline & JIF & $=1.500$ & SJIF (Morocco & $=5.667$ & & \\
\hline
\end{tabular}

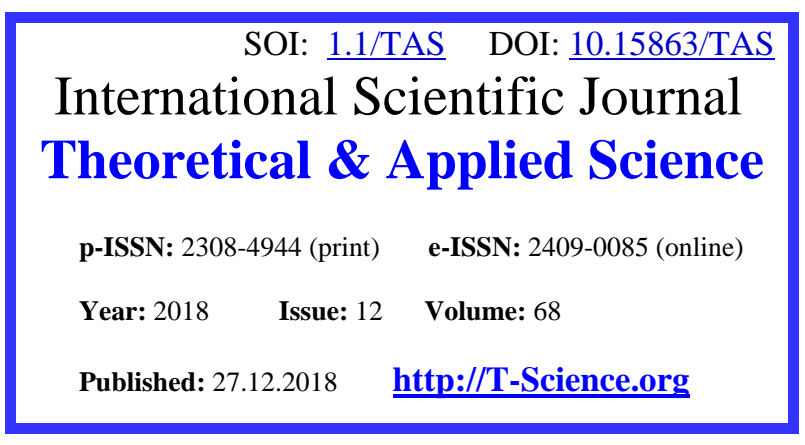

UDC 685.34:335.74

SECTION 33: Advertising technologies.

Creative. Innovations
QR - Issue
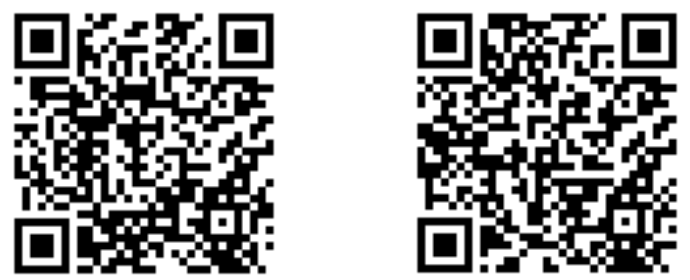

D. O. Borduch

Institute of Service and Entrepreneurship (branch) of DSTU, ( Shakhty, Russia)

A.A. Blagorodov Institute of Service and Entrepreneurship (branch) of DSTU, ( Shakhty, Russia)

V.T. Prokhorov

Doctor of technical sciences, professor, professor of the department "Designing, technology and design", ISOP (f) DGTU, g. Shakhty

N.V. Tihonova

Doctor of technical sciences, professor, professor of the department «Designing clothing and footwear», Research technological University

(Kazan, Tatarstan)

\title{
ACCOUNTING - THE BASIS FOR EFFECTIVE COOPERATION BETWEEN PRODUCERS AND CONSUMERS FOR THE SUSTAINABLE DEMAND FOR MANUFACTURED IMPORT-SUBSTITUTING PRODUCTS
}

\footnotetext{
Abstract: in the message 1 for analysis of a system of indicators for assessing the competitive potential of the enterprise and the importance of consumer properties of products, the authors propose to use a direct estimation method that allowed to obtain a generalized estimation of competitiveness, which on the one hand allows to show the degree of satisfaction with the product, and the degree of use of the competitive potential of the enterprise.

Key words: assessment of enterprise competitiveness and product innovation processes, profit, profitability, import substitution, assortment policy, competitive potential, target segment, the importance of consumer properties.

Language: English

Citation: Borduch, D. O., Blagorodov, A. A., Prokhorov, V. T., \& Tihonova, N.V. (2018). Accounting - the basis for effective cooperation between producers and consumers for the sustainable demand for manufactured import-substituting products. ISJ Theoretical \& Applied Science, 12 (68), 252-262.

Soi: http://s-o-i.org/1.1/TAS-12-68-37 Doi: crossef https://dx.doi.org/10.15863/TAS.2018.12.68.37

\section{Introduction}

In modern conditions of market relations, competitive environment and direct interaction between Russian and foreign producers, the solution of the problem of combining state and market mechanisms of competitiveness management becomes a strategic resource of the

competitiveness was taken by the competitiveness of quality levels, which will increase its relevance with Russia's accession to the WTO. The increase of the quality factor of the results of domestic footwear production in the strategy of competition in the world markets is a long-term trend.
} regional economy of the southern Federal district and the northwestern Federal district. In the world economy, the place of price

\section{Main part}




\begin{tabular}{|c|c|c|c|c|c|c|}
\hline \multirow{4}{*}{ Impact Factor: } & ISRA (India) & $=3.117$ & SIS (USA) & $=0.912$ & ICV (Poland) & $=6.630$ \\
\hline & ISI (Dubai, UAI & $=0.829$ & РИНЦ (Russia) & $=0.156$ & PIF (India) & $=1.940$ \\
\hline & GIF (Australia) & $=0.564$ & ESJI (KZ) & $=5.015$ & IBI (India) & $=4.260$ \\
\hline & JIF & $=1.500$ & SJIF (Morocco) & $=5.667$ & & \\
\hline
\end{tabular}

In Russia, as in most Russian regional entities, there are all necessary conditions for the development of production in the national interest. If somewhere something is not enough, it does not serve as a basis for recession and recession.

In the mid-2010's, the country found itself in an economic situation similar to the end of the 1920s-early 1930s. Then there was a question: whether or not to be a new social order, the desired people (for "elected" always adapt to any situation). The answer was not hidden in the maze, and L. M. Kaganovich did not need a thread Ariadne to get in search of the key to solving the problem to the secret source. He needed the leader's blessing. And I. B. Stalin agreed that "shots solve everything". From ourselves we will specify - "professionally prepared and politically responsible for result". The explanation is important, because democratic reforms in Russia miraculously removed first of all professional responsibility for obvious defects in politics. [1]

Politics has always been understood by all as activities in the interests of the state. Political responsibility in a democratically organized society is the ultimate expression of professionalism. Failure to deliver on political promises and statements indicates either an inability to engage in politics or the use of political governance in the private interest. 85 years ago the obvious for consciousness and was deceptive on practice. In vain, speaking about the cruelty of the I. V. Stalin, forget that every miscalculation in politics affects the situation of the people, not politicians, managers, consultants, advisers.

In the interests of restructuring the economy on the path of increasing the share of added capital in commodity production - in fact, modern industrialization, it is necessary to start not with economic and not with scientific and technical actions-with a political Renaissance. Of course, modern times require different tools than the measures of the second half of the 1930s, but the essence must be invariant. Political efficiency is the highest criterion of professionalism. It is better to interpret this conclusion from the contrary. The actual reality did not reach the declared changes - resignation of managers with the subsequent public characteristic depending on concrete conditions and the size of discrepancy.
In Soviet times party slang was widespread -" to put in a responsible position"! Nobody really knew how to do it, but everyone knew, if not run, will be bad. We have the same reason, the responsibility shifted to the market. Responsibility for the implementation of specific political directions, losing a personified form, ceases to be a responsibility. The Duma, we would not respond. The government is responsible to the President and the Duma. The President is solely personally responsible to the people. Hence the only worthy rating of the people's poll. Undoubtedly, The President was helped by his Patriotic policy - consistent, active. But, it seems that the main factor, albeit not obvious, in the President's popularity, in contrast to all those vested with power, is his practical capacity, motivated by high political responsibility.

Unfortunately, while the knots tied by economic incapacity and impunity will be unleashed by the President, and responsible for the solution of the problems facing society, will continue frankly to drag out time, being covered by uncertainty of interpretation of modernization, our General task "to get rid of commodity dependence" $-55 \%$ of tax revenues, won't be solved. [3]

The personification of responsibility does not mean a search for the one responsible for everything. Personification implies delegation of responsibility for obtaining the desired result. It is essential to realize that " team "is not a company of like - minded people, colleagues, partners;" team " is a chain of responsible, due to the specifics of the object and the problems of its modernization. Responsibility for the result should not be smeared in the bowels of the team. Responsibility even for the team result always has a personal expression, which in the focus do not want to recognize our senior managers. It is this desire - to "push" everything on the specifics of the object of management, the unpredictability of demand, currency volatility, incomprehensible changes in tariffs, etc., that can explain the pressure "from above", with which we prove that management is a professional direction, not an add - on over the subject originality and systemic position of a certain production.

A curious fact, however, is not from the history of "light" industry. D. Mendeleev in the early XX century was instructed by the Government to deal with the secret of 


\begin{tabular}{|c|c|c|c|c|c|c|}
\hline \multirow{4}{*}{ Impact Factor: } & ISRA (India) & $=3.117$ & SIS (USA) & $=0.912$ & ICV (Poland) & $=6.630$ \\
\hline & ISI (Dubai, UAE & $=0.829$ & РИНЦ (Russia) & $=0.156$ & PIF (India) & $=1.940$ \\
\hline & GIF (Australia) & $=0.564$ & ESJI (KZ) & $=5.015$ & IBI (India) & $=4.260$ \\
\hline & JIF & $=1.500$ & SJIF (Morocco) & $=5.667$ & & \\
\hline
\end{tabular}

modernization of gunpowder in Germany. Not having direct access to German technology, chemist has requested monitoring of the movement of freight trains in places where gunpowder is produced by tracking the beginning and end of routes. On the basis of the received information, he deciphered the German recipe and developed recommendations for the Russian Government. There would be a pure economist, a modern top Manager in his place, the result would be absolutely different. He would be involved in the statistical and financial calculations of expenditure and income, leaving the political, scientific and technical components. The most serious methodological mistake is to reduce economic policy to economic analysis.

Economic science has emerged and evolved in the context of politics as a political economy. Today, economists in politics are guided not by political economy, but by Economics in politics. Instead of investing in the development of production, they hide money in foreign banks, reduce funding for education and self-education, increase the number of poor people, do not index pensions, refuse to help farmers, etc. "Manila" of the nineties replaced the "buns" of the tenth.

The main and invariant superiority of Russia lies in the geographical position, combined with the lack of danger of overpopulation of our space due to natural growth. We have a natural and solid margin of safety for centuries. Instead of pressing past the irrationality in politics and the economy, would have to pay for the actual merits of our ancestors, has managed to amass Russia and peoples around Russia. Not so much worried about the decline in production, squandering what has historically manifested its national identity, national traditions as the possibility of loss of employment talent of the peoples of Russia, the alarming system of the ineffectiveness of economic policy.

Progress does not happen without deviations, slowdowns in movement, recessions. Policies are designed to help overcome obstacles to development through active, focused action. Politicians should be ahead of the economic movement and direct it, stimulate domestic economic factors with political levers, clear economic ways to effective production. Instead, politicians continue to link the development plans to the price of oil, the ruble, the size of the European and American currencies, referring to integration trends in the world and globalization.

The integration of transnational relations is an objective reality, but for all its objectivity it does not deny the specifics of national economic progress. Moreover, integration is objectively designed to promote national development. Why we did not work as it should be? This question arises from a logical comparison of policies in the field of strengthening defense capabilities, restoring the international credibility of the country in the difficult circumstances of the formation of a new world architectonics with the fact that from year to year the Russians see and fully feel in the field the rest of the economy we have not accidentally two governments? The second "presses on the gas and brakes" at the same time.

The protracted recession in the Russian economy has: two ways to explain. The first-the people lost ability to work well, spent "human capital", the second - managers are helpless. The media assure that politicians know their business, keep events under control, take necessary measures and promise changes for the better in the near future. Therefore, the reason for the poor performance of performers and unfavorable world conditions.

How naive is it to be when planning economic policy, based on sincerity, unselfishness, sympathy of competitors? The Russian President has long said that our Western partners do not want to strengthen Russia, they need obedient Russia, such as the Baltic republics that were formerly part of the USSR. I did not want to sadden politicians responsible for the economy, but following Aristotle, forced to state: "Friends in the East, too, to his mind" - in the sense of "Plato is a friend to me, but the truth is more expensive." They will help us as they benefit from such assistance.

It is time to understand that all economic and political unions in the modern world space are an attempt to achieve national gains in transnational relations, i.e. partners can be expected as long as they benefit from this cooperation. It follows from this conclusion $-\mathrm{a}$ person must stand to its economy. Only in this way, albeit with great tension, will be able to solve their problems. There are, for example, such objective reasons that would justify the 


\begin{tabular}{|c|c|c|c|c|c|c|}
\hline \multirow{4}{*}{ Impact Factor: } & ISRA (India) & $=3.117$ & SIS (USA) & $=0.912$ & ICV (Poland) & $=6.630$ \\
\hline & ISI (Dubai, UAI & $=0.829$ & РИНЦ (Russia) & $=0.156$ & PIF (India) & $=1.940$ \\
\hline & GIF (Australia) & $=0.564$ & ESJI (KZ) & $=5.015$ & IBI (India) & $=4.260$ \\
\hline & JIF & $=1.500$ & SJIF (Morocco) & $=5.667$ & & \\
\hline
\end{tabular}

decline in production in light industry for a quarter of a century.

Light industry, closely related to agriculture, is really dependent on the work of the latter. Only such interaction should be approached historically specifically, based on scientific and dialectical analysis. There are old weather reports showing that out of 10 calendar years in Russia 5 are unfavorable for the development of agricultural production $(2+3$ and $3+2$ ). In determining the" five-year plan " as a planning measure based on this pattern.[4]

The problems of agriculture and light industry are not in their specifics, they have always been political. In the US, Europe, farmers have a lot of our problems. The difference is that there is a farmer - a national problem among the most important, the main. Its consideration is relevant to the existence of politicians. On how a policy contributes to the resolution of the estimated public policy. The farmer and the politician are connected by economic policy. They balance on one tight economic tension "rope" of viability.

Nothing similar in Russia there is no. Let us recall the history of the last Ministers of agriculture. In the USSR there was a Ministry of light industry, which emphasized the importance of the industry. What prevents in the conditions of import substitution and declarations on the importance of developing their own production to restore equality in industrial management. "Calico land" without the light industry is still that the native nature without the birch trees or lyrical poetry without creativity Esenin. [4]

Reformers of the 1990s the fate of the Fatherland and domestic industrial identity the least worried. They built the business on the ease of maximum profit and placed the walrus away from the land of their ancestors. Light industry has traditionally been a tough challenge to manage. Managers need to be, above all, patriots, otherwise the industry is not easy to raise. It is also necessary to understand the national importance of "long money". The sustainability of demand would compensate for the difficulties.

What is the essence of ineffective politics in the economy of the late past and the beginning of the new century? This is question No. 1, and it is not so much about who is to blame. We are interested in the essence of the political paradigm developed by those who found themselves at the helm. Question No. 2 - what should be changed and how, apparently, it has to be done to raise the national industry, production of clothes, shoes, leather goods, textiles, accessories last but not least?

The answer to question 1 is simple - no one was going to develop a paradigm of economic policy aimed at a radical transformation of the basis. The way to reform (not without assistance) decided to pick from the ready samples. It was proposed to take Swedish experience, Polish "shock therapy", reforms in Portugal and Argentina as a model. Such innovators, brave scientists, wise organizers as Gaidar, Chubais, Koh, Burbulis did not come up with the idea, which usually begins a responsible host - what I have to copy something. [5-6]

Policy is not made depending on the state of feelings. Like or dislike - the level of everyday perception of the world. With this approach in the "political kitchen" is harmful to be. Economic policy does not fit into "good" or "bad", "effective", or "ineffective." It has the right to be called either "useful" or "harmful". The price of such a policy is too high, respectively, and responsibility is not limited to professional form. Politics is politics. It is antipolitical and unprofessional to make politics a source of their own income.

Whatever the economic situation, it is extremely dangerous to absolutize the importance of economic criteria, to give them the property of universality. Engels spoke out strongly against attempts to reduce the doctrine of Karl Marx about community development to "economic materialism", "economic determinism." Economic basis-the basis of social organization, but not the backbone factor of its improvement.

Society is a system of human relations carried out in the dynamics of economic activity. Activity-means of social life of people. Activities that determine the need for all kinds of relations - a way of manifestation and development of man. Relations are designed to ensure such human development. About the fact that the form of ownership needs to be changed, at the end of the XX century did not say only dumb, but that the relationship born of the form of ownership, pull the distribution of the produced product, or its monetary equivalent, that the exchange can not be fully trusted the market, control functions need to keep the state, rebuilt democratically, that in a perverse 


\begin{tabular}{|c|c|c|c|c|c|c|}
\hline \multirow{4}{*}{ Impact Factor: } & ISRA (India) & $=3.117$ & SIS (USA) & $=0.912$ & ICV (Poland) & $=6.630$ \\
\hline & ISI (Dubai, UAE & $=0.829$ & РИНЦ (Russia) & $=0.156$ & PIF (India) & $=1.940$ \\
\hline & GIF (Australia) & $=0.564$ & ESJI (KZ) & $=5.015$ & IBI (India) & $=4.260$ \\
\hline & JIF & $=1.500$ & SJIF (Morocco) & $=5.667$ & & \\
\hline
\end{tabular}

bureaucratic form, the state remains the generator of corruption, trying to keep silent, understanding the delicacy of reforming property.

Most of the population is not relevant in who the owner, not everyone wants to try on the functions of the owner-to spin, twirl, fight, risk. The distribution, on the contrary, concerns everyone, both poor and non-poor.

Reliability and versatility are the hallmarks of quality of knowledge. Reliability allows to minimize risks, universality relieves tension from search of new solutions of a problem "from good don't look for". For the quality of account for to pay. The fee, as is commonly believed, has a financial relationship, but it doesn't always look directly. In the history of civilization, there are two outstanding achievements at the level of revolutions, clearly not received an equivalent assessment, namely:

the discovery of the price of knowledge, comparable to the price of things for a person, "knowledge is power"; the realization of the special meaning of theoretical knowledge in the form of concepts and related forms of abstract thinking - judgments, conclusions. This naturally led to the need to develop a specific technology of their production - a methodology for learning the essence of the relationship of existing phenomena. The visible part of the world is "designed" for the consumer, the invisible - for the manufacturer. The competition of producers can be formalized in the form of a simple technical task - to penetrate through the chaotic set of phenomena of the visible part of the world into its hidden part, to understand it, having returned, to understand chaos as an order of coexistence and development of phenomena. Order and there is a pattern. Laws only in textbooks exist by themselves, separately. In fact, the law is the stability, commonality and necessity of the order with which we interact - we learn, reproduce, change, manage.

Economic science in the twentieth century fell into a difficult situation, which by the end of the century became critical. The theory of A. Smith and the method of K. Marx did not fit into the contours of the ideology of developed capitalism. In Europe and North America, the very idea of the historicity of capitalism was perceived as heresy. The history of capitalism has a beginning, but the existence of a beginning cannot be the basis for a conclusion about a limb. Mathematics is an exact science, it allows for infinity in one direction. The dialectical interpretation of infinity is a metaphysical, abstract from the real story. The salvation of economic science should not be sought in historical, but formal-logical understanding of reality, that is, in mathematical calculus, statistics.

We will stop the immersion in philosophical, more correctly, in the methodological foundations of science, but not because it is necessary to plunge into practice faster, but because of the importance for the successful realization of the production of goods understanding that any production involves the reproduction, along with the goods, relations. Production begins with the achievement of certain relations and leads to the development of these relations - between producers and consumers. It is possible to understand so difficult built production only with involvement of the scientific analysis on the basis of conceptual thinking.[3-4]

That is why we have to start the analysis of the comparative new concept of "attractiveness" in its applied concrete expression "attractiveness of goods", from the theory, logical doctrine. There is an alternative way, but without a light source, by touch, in the dark.

Modern knowledge of the concept; its ascent from abstract to concrete with the subsequent prospect of the birth of new concepts as products of the development of content, G. Hegel laid. Conceptual thinking, according to Hegel, is a dialectical process. The teaching of the world-famous philosopher was based on a fundamentally new interpretation of development, which was based on the idea of an internal source of movement represented by the relations of opposites in unity. The predecessor of Hegel, Aristotle, the logic of thinking was built on the principle of identity of the concept itself, its immutability. In mechanical theory, this approach is reflected in the section" statics", and the expert knows that in this way the situation is artificially simplified in the private interest. However, the sections "dynamics" and "kinematics"are the most interesting in practical terms. They describe not the moment of movement - generally interpreted as something not changing, resting in its state, but the movement itself as a change in the broadest sense. Before the dynamics and especially kinematics of thinking in the context of the 


\begin{tabular}{|c|c|c|c|c|c|c|}
\hline \multirow{4}{*}{ Impact Factor: } & ISRA (India) & $=3.117$ & SIS (USA) & $=0.912$ & ICV (Poland) & $=6.630$ \\
\hline & ISI (Dubai, UAI & $=0.829$ & РИНЦ (Russia) & $=0.156$ & PIF (India) & $=1.940$ \\
\hline & GIF (Australia) & $=0.564$ & ESJI (KZ) & $=5.015$ & IBI (India) & $=4.260$ \\
\hline & JIF & $=1.500$ & SJIF (Morocco) & $=5.667$ & & \\
\hline
\end{tabular}

content of the movement of concepts Aristotle did not get, he was primarily interested in the technology of abstraction and generalization in the forms of knowledge. Aristotle's logic is therefore often called "formal".[1]

From Hegel's point of view, Aristotle's logic was just a special case, having value in the fact that knowledge in order to integrate into the process and conduct a General reconnaissance, it is important, albeit conditionally, to stop the change. Aristotle sacrificed the content of concepts in order to achieve the regularity of formal relations. Simply put, the view of Aristotle's logic is akin to the expression "General plan" for the time being. The past and future of the concept Aristotle was not interested in that, again, in General, consistent with the nature of historical time. K. Jaspers called the described era "Axial time", emphasizing the role of culture as the axis around which the Ancient civilization began to unfold, but it is hardly necessary to see in its assessment the actual historical scale of the changes that took place, and the very understanding of time by the Greeks was cyclical. In short, Aristotle in his logic reproduced the spirit of the era in which he lived and worked. Another thing is Hegel who worked in conditions of prosperity of New time with its political, scientific, technical, industrial and cultural revolutions. G. Hegel needed to understand the spirit of time in the context of radical social changes, to fill the content of concepts with movement.

After Himself, Hegel left a lot of questions, so paying tribute to his dialectical discovery, it should be remembered about the Hegel legacy, which hindered the spread of dialectics.

Limiting dialectics to the sphere of spiritual activity, he recognized the self-sufficiency of being of the spirit and perceived everything else in the form of being of the spirit, of course, outside the dialectical development. The triad of G. Hegel's "thesis - antithesis - synthesis" was not a universal formula for development. The existence of nedogony forms of existence physical reality of human nature, of society, he explained the objectification of the spirit, referring to the derivatives of the spirit. The merit of K. Marx and F. Engels was just that, relying on the natural scientific discoveries and movements of the bourgeois method of production, they first turned the understanding of dialectics "from head to foot", and then removed the restrictions from it and made a universal way of development.[5-6]

Reaction on rationalism Hegel's were and positivism, and irrationalism, but they have suffered the same "disease", that and "sick", one-sided approach. Positivism clearly experienced the limitations inherent in empiricism, irrationalism was closer to the time of bourgeois activity, not burdened by intellectual reflection, the idea of willpower, the desire for power, received some support in a developing society, despite a number of leading conclusions from the point of view of cultural traditions.

This is confirmed by another surge of interest in Europe in K. Marx's economic research at the end of the nineties in connection with the financial crisis. Europeans are not aware that there is another serious monograph of Lenin's "Imperialism as the highest stage of capitalism", in which the author for the first time analyzed the leading dynamics of financial capital and noted his Frank desire for political influence on social life.

Dialectical thinking did not come to the economy at once, it began with individual ideas, mainly ideas of development. Italian economist A. Serra was the first to pay attention to the division of labor (RT) and looked at this feature of economic activity in dynamics. Statistically, he proved that the country's wealth grows depending on the depth and spread of RT. William petty and Adam Smith turned the angle of the output A. Serra at the transnational scale. As a result, A. Smith found himself in a deadlock of non - dialectical reflections-when RT will cover the economy of the whole world, will development stop? A. Smith and D. Ricardo took capitalism is identical with the history of the world, were convinced that capitalism appeared to be endless. Economic thought has gone to its limit, for it has not been able to find a political beginning equivalent to economic. Marx predicted that the logic of economic development would inevitably lead to political and social metamorphoses, setting against itself the apologists of capitalism.

It is no coincidence that in the XX century the political component of economic science was vigorously squeezed out, naively believing that it will be possible to limit itself to purely economic analysis. The very "purified" economic science was divided into macro and microeconomics, and by the 21 st century it was 


\begin{tabular}{|c|c|c|c|c|c|c|}
\hline \multirow{4}{*}{ Impact Factor: } & ISRA (India) & $=3.117$ & SIS (USA) & $=0.912$ & ICV (Poland) & $=6.630$ \\
\hline & ISI (Dubai, UAF & $=0.829$ & РИНЦ (Russia) & $=\mathbf{0 . 1 5 6}$ & PIF (India) & $=1.940$ \\
\hline & GIF (Australia) & $=0.564$ & ESJI (KZ) & $=5.015$ & IBI (India) & $=4.260$ \\
\hline & JIF & $=1.500$ & SJIF (Morocco) & $=5.667$ & & \\
\hline
\end{tabular}

generally presented as Economics. "The new economic "science" writes M. L. Khazin, it was created as an ideological alternative to political economy... for this purpose it was necessary to turn the construction of science upside down: if political economy is built on macroeconomics (ie. the General economic laws, which include the deepening of the RT, the scale of markets, and the volume of total demand) to microeconomics (i.e., the behavior of an individual and an enterprise), then in Economics everything is the opposite, i.e. the specifics of Economics is an attempt to withdraw from the microeconomics global macroeconomic laws."

Now imagine the scene - experts manipulate historical science, instead of to improve its methodology, to generate new theoretical research to build and rebuild through a systemic approach tried and tested ideas. The question is, why? Who needs this? In theory of knowledge on these questions answers are not provided. The absurdity of the denial of the logical paths of the movement is obvious, although there are precedents. Famous scientists have repeatedly pointed out the illogicality of the achievements of the discoveries made, but they talked about the final heuristic link logically and methodically built a chain of knowledge. Illogical or, more precisely, illogical final results only confirmed the rational prospects of logically organized thinking in both versions - Aristotelian and Hegelian.

Scientific concepts have great potential for development. Systemic relations of concepts contribute to the emergence and actualization of new concepts. New concepts may well grow into strategic ones. On the other hand, G. Hegel considered it important for the correct orientation in the real world, to distinguish between really necessary and really unnecessary. The first contains the source of functioning and development, so he called such phenomena "reasonable" or "valid", the second served and either slows down the movement or counteracts it.[2]

It seems that economic science in both the West and Russia, under the influence of the Nobel prize winners, has decided that with The death of Hegel and Marx, political economy has died. But the impression is false. Having noticed a priority of production in construction of economic system on a factor of the market modern scientists economists changed owners. To replace F. Taylor, A. Faiola, G. Ford, A.
Sloan came market speculators of the type of Soros, and policy guidance from economic theory are preserved.

It is necessary to put capitalism over history as an ideal model of production organization. Formally, the combination of a developed form of political democracy, its legal support by the state, with the freedom of entrepreneurship gives rise to a claim to perfection. But let's not forget that all of the above looks perfect in comparison with the political and legal models of absolutism, dictatorship and other anachronisms. The story does not end with the financial-oligarchic capitalism with its showcase demonstration of the society of mass consumption. The" casting " of model socio-economic models continues and will continue until the current model is available to the seventh part of humanity. Six and a half billion of the same homo sapiens can still afford to buy a movie ticket at best and see the sweet life of their own kind. Seven with a nipple against one with a spoon-the proportion is very dangerous, besides, the figure itself is seven on a special account in the practice of social consciousness.

The world conference of the elite of the scientific world in Rio strongly recommended to change the course of business greed for sustainability, warning that the aggravation of human contrasts will join the global conflict with nature. Instead of the noosphere, the next generation, born now, will receive gas masks and protective suits, and light industry will have to change directions of development to provide the endangered species of mammals with individual means of protection.

The features of the dominant mode of production certainly manifest themselves in the development of economic science, but they do not cancel its political status. Moreover, economic science, before making another round of progress, is objectively obliged to determine the political prerequisites for the rise of the method of production to a new level. Try to understand, what more is left to the heirs of A. Smith, D. Hume, R. Owen, J. Sismondi, Marx, John. Mill, H. Spencer, T. Malthus, a socio political philosophy or economic knowledge. In their writings, social history was transformed into political history, and politics they left as a means and purpose of economic programs to advance in solving problems of social development. The Communist alternative to the 


\begin{tabular}{|c|c|c|c|c|c|c|}
\hline \multirow{4}{*}{ Impact Factor: } & ISRA (India) & $=3.117$ & SIS (USA) & $=0.912$ & ICV (Poland) & $=6.630$ \\
\hline & ISI (Dubai, UAE & $=0.829$ & РИНЦ (Russia) & $=0.156$ & PIF (India) & $=1.940$ \\
\hline & GIF (Australia) & $=0.564$ & ESJI (KZ) & $=5.015$ & IBI (India) & $=4.260$ \\
\hline & JIF & $=1.500$ & SUF & & & \\
\hline
\end{tabular}

bourgeois method of production objectively has not yet matured. The desire to divide the history of communism politically into two stages and to begin with socialist was blocked, on the one hand, by the politicization of the economy of capitalism in the direction of strengthening socially significant milestones, on the other aggressive economic policy called protectionist collusion, and ordinary political deception is not to the best of trusting leaders of Communists to convince socialism of economic insolvency. The truth remained concrete-the political resources of economic science are determined objectively by the historical time of the method of production by which it was born. Economic science is United by its objectivity, but its objectivity reflects historical epochs and therefore has the form of a chain composed of individual specific historical links, naturally connected with each other. Perhaps temporarilysuch links exist. Such experiences were calculated by V. I. Lenin NEP stand for them to fight with the allies and caused the economy of the country, and the official political doctrine of China: one country - two system.

The modern history of economic science, contrary to the numerous tricks of opponents, is the same political course, depoliticization of economic theory absurd looks in economic practice. It is enough to look at the movement of exchange rates, to trace the exchange news to assess the strength of the political impact on economic activity.

Together with the evolution of economic science, economic concepts are changing, some are rebooting, filled with new content, others are pushing the area of application, others are moving to new positions, the fourth lose their former importance while the fifth appear, demonstrating the modernization of economic reality. Moving from concept to concept you can repeat the historical logic of the rise of the production to determine the quality of historic racing.

The market became the basis of the exchange action, and a fair addition. The nature of the market is determined by the need for reproduction. The market is inscribed in the production process and all its attempts to rise above the production are unnatural. But the very existence of the market as a way to meet the conditions of reproduction is absolutely natural, which allows the market to show its legitimate position in production within certain limits. As everyone knows, one can Express oneself in different ways, especially since the market unites the interests of different subjects of production, each of which wants to be a winner.

Production unites not only technical and technological actions, their objectively dependent organization, it includes the "human factor", which in recent years is often called "human capital"-it sounds more pleasant, inspires pride for the right to be a "reasonable person", in addition, almost capitalist. "Human factor" more accurately describes what is happening directly in the production, as production can be unfolded without a trace on the basis of the concept of "factor" into the components of "didactic" units. "Human factor" brings to production the goal, if you are lucky with the "human capital" - the professional culture of management, from the goal you can" grow " expediency, that is, systematically organize the relationship of the goal, means, methods and forms of its achievement, to optimize the production process. In General, production looks like an activity to turn a goal into a result. The correct choice of the goal of production is considered the first victory, the "good beginning" that folk wisdom is equivalent to "half things".

And yet, " the end is the crown." The goal is realized, the desired result is obtained. A new story begins. The result is not produced for own consumption. In order not to stop production, and the victory was not Pyrrhic, the resulting product in the rank of the goods must be exchanged for the necessary conditions for the continuation of production. The case includes the market, whose task is to attach the goods-to find a buyer. The buyer, of course, their interests, perhaps not quite personal, on the contrary, in the first place, production. To some extent, the market is also a production, it makes the organization of intermediary services. This production, however, is more like rzezpospolita, for it is not the function of the added value of the product, but actively influence the change of the product. The very concept of "price" market origin, therefore, is indirectly related to the indigenous concepts of production" cost "and" value " of the goods. Price provides profit to the market and the market is an interested subject of the pricing process. Here begins another interesting story for the buyer. The market has great opportunities to manipulate goods and prices in the absence of a clear 


\begin{tabular}{|c|c|c|c|c|c|c|}
\hline \multirow{4}{*}{ Impact Factor: } & ISRA (India) & $=3.117$ & SIS (USA) & $=0.912$ & ICV (Poland) & $=6.630$ \\
\hline & ISI (Dubai, UAE & $=0.829$ & РИНЦ (Russia) & $=0.156$ & PIF (India) & $=1.940$ \\
\hline & GIF (Australia) & $=0.564$ & ESJI (KZ) & $=5.015$ & IBI (India) & $=4.260$ \\
\hline & JIF & $=1.500$ & & & & \\
\hline
\end{tabular}

thought-out and organized interaction in the system of relations between producers and consumers. Liberal political economy focuses on the freedom of the market, not caring about the content of the concept of "freedom". By arbitrarily invading philosophy's sphere of responsibility, liberals pretend to solve their problems by misleading professional thinking and public consciousness. Not all economiststheorists and practitioners are tempted in philosophical reflection. Taking advantage of this position, liberals grow their market "concept" freedom, trying to free the market from subordination to the need for any expression. In fact, economic liberalism proclaimed by A. Smith in a specific format was transformed into banal market anarchism. In countries where democratic traditions are strong, loaded with humanistic values and social responsibility, liberalism is losing political ground, but it has a serious roof in the face of thriving financial capital chewing at the expense of the market.

We do not want to deprive the market of the status of a subject of developed cultural production. Market without any doubt they are, but to put the market in a common number of subjects of production, therefore, ignore the evidence of different attitudes to the most important indicator of the development of production - the ability to work hard to increase the cost.

The freedom of the market is comparable to the freedom of judges on the football field. Judges do not play, they provide the game under the current rules. They can slow down the pace by their actions, bring down pressure, play along, but all this takes place in plain sight, under public and professional control and is prosecuted in accordance with the established procedure.

The exchange function of the market objectifies it, but it is important to remember the methods of manifestation of objectivity. The material form of objectivity - the technical and technological objectivity of production, the physical reality of the goods - is really primary and subject to the natural basis of social life; the objectivity of industrial and economic relations, including the organization and division of labor - "secondary" objectivity, created with the creative participation of the subjects of labor is naturally historical objectivity. There is still, presumably, a third, transitional level of objectivity, indirectly controlled by the objective nature of production. The market belongs to this third level. Hence, such a different reality of the market, the ability of the organizers to manipulate quite arbitrarily within the market and in the interests of the market. F. Engels explained to E. During: "in a society where commodity production is the dominant mode of production, "the market has always been ... the boundary of a very well-known among"business people". Due to its specific reality of the "transitional type" from the rigidly regulated existence of production to the relativity of the dependence of the exchange conditions on the natural-historical specificity, the market combines the adequate validity of the action with the actions of a specific property, organizing its infrastructure from the latter. Covered "marketers" "iron argument" - the market "barometer" state of production. In a similar position, all those actions that, according to the classification of Hegel, are not valid, allowed as necessary-conditional. Quite logically, Petzold, who saved the machismo from solipsism by introducing into the formula of being "a potential member of the"relationship". Petzold did not personify the "potential member", but it was not difficult to understand that they should be something universal, standing over the subjective form of consciousness. Marketers, absolutizing the position of the market, or rather, exchange through the market, achieve control over production. The interest of marketers again makes us remember the power of money.

In its objective position, the market should not earn more than producers. Otherwise the production will stop, and with it social progress. Now the situation is critical, the first cause of the crisis is the policy of financiers, the second market speculation. Prices for real goods on the market for a long time do not correspond to the cost of their real production delivery and selling costs. The problem is for liberals in one thingthe education of the masses. Still on the street twenty-first century. Therefore, the world policy in the sphere of modernization of education is aimed at its "market" division. The vast majority of graduates are doomed to be clerks, a clear minority, mostly of their own, plus those who are particularly talented, is the reserve of top managers. It's not about the name of the University, it's about the interest in you, very rarely depending on you. 


\begin{tabular}{|c|c|c|c|c|c|c|}
\hline \multirow{4}{*}{ Impact Factor: } & ISRA (India) & $=3.117$ & SIS (USA) & $=0.912$ & ICV (Poland) & $=6.630$ \\
\hline & ISI (Dubai, UAI & $=0.829$ & РИНЦ (Russia) & $=0.156$ & PIF (India) & $=1.940$ \\
\hline & GIF (Australia) & $=0.564$ & ESJI (KZ) & $=5.015$ & IBI (India) & $=4.260$ \\
\hline & JIF & $=1.500$ & SJIF (Morocco) & $=5.667$ & & \\
\hline
\end{tabular}

The rise of the market and its infrastructure is due to the birth of mass production. At the first level of mass production, the market was as regulated as possible by the task of deploying the sale of goods on a production scale, so that reproduction was dynamic. Over all dominated by the need for production in working capital, as the advantage of mass production is the ability to reduce costs, thereby reducing the cost and increasing the competitiveness of the goods. The key factor was the time of sale of goods. "Time is money". Mass production has generated a trade principle: the consumer can not find what he is looking for! Universal makemagazine offered almost the entire product range of the product in all its possible diversity, including price. It soon became clear that the lack of certainty is associated with high costs of raw materials, energy, maintenance of premises, a large number of unrealized products, especially limited shelf life. The market failed to cope with its function as planned. There was an important event that did not receive a well-deserved assessment, perhaps did not want to reduce the reputation rating of the market. Production workers "went to the people" - to study demand taking into account social stratification. The matter is troublesome, the achieved certainty is not as accurate as desired, but even at the conditional level it serves as the basis for orientation for production planning.

The slipper fell into place and by the time Cinderella in the fairy tale, and that because she was her second slipper, however, marketing research is really essential to all subjects.
Manufacturers are cutting costs, consumers receive a more reliable guarantee to purchase the desired product, intermediaries lose their former freedom to manipulate the goods and prices. But it is not appropriate to get involved in the assessment of transformation. The market for the three hundred year history of industrial production has developed a protective and compensatory mechanism from the "impact" and from below-manufacturers, and from above - rulers, the same sad that the market through lobbyists grew into power, consolidated their interests in the wording of laws, their interpretation. The second pillar of his became the mass media, going without thinking about any violation of the regulatory limits on commercial advertising, engaged in advertising and "in white" and "in black"-in extracurricular time.

\section{Conclusion}

Information of the General - purpose market. It is included in the essence of the functioning of the market and has changed throughout the history of the market. It is equally obvious that market information developed faster than the basic part of the market, formed in a separate segment of the market reality, which has its main reason for increased competition between producers of goods became more and more in the market, and the number of producers grew. The market itself eventually became a subject of competition, actively involving advertising and means of its distribution

References:

1. Prokhorov, V. T., et al. (2012). Managing production of competitive products in demand. under the General editorship of doctor of technical Sciences, Professor V. T. Prokhorov (Eds). (p.280). Novocherkassk: yurgtu (NPI).

2. Train, Y. M., Polukhina, S. Y., Osina, T. M., Kononenko, E. V., \& Meleshko, E. N. (2014). On finding funds impact the cash flows on the performance of footwear enterprises in the regions of SFD and NCFD. Innovative development of light and textile industry" (INTEX-2014): abstracts of all-Russian scientific student conference. (p.116). M.: FGBOU VPO MSUDT.

3. Prokhorov, V. T., et al. (2014).The quality revolution: through the ad or through a quality real. monograph. under the General editorship of doctor of technical Sciences, Professor V. T. Prokhorov (Eds). VoIP (branch) of DSTU. (p.384). Novocherkassk: URGU (NPI).

4. Prokhorov, V. T., et al. (2010). Modern approaches to ensure demand for the products of Shoe enterprises of the southern Federal District. the monograph [Text] [etc.]. under the 


\begin{tabular}{|c|c|c|c|c|c|c|}
\hline \multirow{4}{*}{ Impact Factor: } & ISRA (India) & $=3.117$ & SIS (USA) & $=0.912$ & ICV (Poland) & $=6.630$ \\
\hline & ISI (Dubai, UAE & $=0.829$ & РИНЦ (Russia) & $=0.156$ & PIF (India) & $=1.940$ \\
\hline & GIF (Australia) & $=0.564$ & ESJI (KZ) & $=\mathbf{5 . 0 1 5}$ & IBI (India) & $=4.260$ \\
\hline & JIF & $=1.500$ & SJIF (Morocco) & $=5.667$ & & \\
\hline
\end{tabular}

General editorship of Professor V. T. Prokhorov (Eds). (pp.29-137). Mine: Publishing house GOU VPO yurgues.

5. Biryukov, A. N., Borilo, E. V., Glushchenko, O. I., \& Aspen, T. M. (2014). The regional economy: development trends. the monograph. (p.159). Voronezh : vgpu.

6. Getmanova, E. F., et al. (2016). I. S. Shrivel import Substitution footwear at the expense of informed decision assortment policy to ensure consumers popular shoes. II international scientific and practical conference "Models of innovative development of textile and light industry based on the integration of University science and industry. Education-scienceproduction" : collection of articles. 23-25 March 2016; M-in the way. and science of
Russia, Kazan. NAT. issled. tekhnol. Univ. of Illinois. (pp.335-341). Kazan : Publishing house of KAZAN state technical University.

7. Reva, D. V., Korablina, Y. S., Prokhorov, V. T., Narozhnaya, I. G., Tikhonov, N. (n.d.). Formation of import-substituting assortment of shoes for domestic markets. pp. 364-371

8. Engels, F. (1961). Anti-Dühring. K. Marx and F. Engels. CIT., Ed. watt. (pp.5-342). M.: Gospolitizdat. 20.

9. (2014). The big book of Eastern wisdom. (p.800, p.410). Moscow: Eksmo.

10. Hegel, G. (1975). Encyclopedia of the philosophical Sciences 1. Science of logic. (p.452, pp.341-342). M.:Mysl. 